\title{
Cost Accounting as a Possible Solution for Financial Sustainability of Croatian Public Hospitals
}

\author{
Ivana Dražić Lutilsky \\ University of Zagreb, Department of Accounting, Faculty of \\ Economics and Business, Croatia \\ idrazic@efzg.hr

\section{Berislav Žmuk} \\ University of Zagreb, Department of Statistics, Faculty of \\ Economics and Business, Croatia \\ bzmuk@efzg.hr

\section{Martina Dragija} \\ University of Zagreb, Department of Accounting, Faculty of \\ Economics and Business, Croatia \\ mdragija@efzg.hr
}

\author{
CroEconSur \\ Vol. 18 \\ No. 2 \\ December 2016 \\ pp. 5-38
}

Received: March 18, 2016

Accepted: October 4, 2016

Research Article

doi:10.15179/ces.18.2.1

\section{Abstract}

The purpose of this paper is to present the current usage of cost accounting methodology in Croatian public hospitals through conducted empirical research and to provide opinions of accountants and financial officers regarding possible implementation of cost accounting methodology in public hospitals. In the paper, the authors analyze the accounting system in Croatian public hospitals, identifying the flaws of the current accounting system with regard to the recording and allocation of costs. National healthcare systems of different European countries provide a theoretical background for the usage of accrual accounting basis and cost accounting methodologies, showing better governance and financial sustainability of public hospitals which have introduced cost accounting methodology. The conducted empirical research shows that accountants and financial officers believe that the healthcare system in Croatia is ready for a change in the current accounting system based on the modified accrual 
basis through the implementation of accrual accounting basis and full costing approach to cost allocation. Full costing approach is also known as activity-based accounting method for cost allocation. The authors also recommend some initial steps for implementation of the new cost accounting system in Croatian public hospitals.

Keywords: accrual accounting basis, cost accounting system, public hospitals, financial sustainability, statistical analysis

JEL classification: $\mathrm{H} 83$, I18

\section{Introduction 1}

In the last decade, we have witnessed constant reprimand of the Croatian national healthcare system (NHS) for its piled-up debts. Changes in the financing of public hospitals, long patient waiting lists and constant increase in public hospitals' expenditures forced the government to issue the Rehabilitation Law in January 2013 (Official Gazette, No. 136/2012, 151/2014). Financing of the Croatian NHS, through diagnostic related group (DRG) methodology, was aimed at an equitable distribution of income, especially in hospitals and clinical centers, according to the capacity and volume of provided services. However, in setting up the aforementioned methodology, the actual cost of provided services was not taken into account, in particular fixed costs of hospitals which primarily depend on the size and equipment of the public hospital (Vašiček et al., 2016). The procedures in NHSs of other countries in applying similar methodology for determining the diagnostic related groups specifically take into account the cost structure. The DRG methodology is a patient classification scheme which provides a means of relating the type of patients' hospital treatment (i.e., its case mix) to the costs incurred by the hospital (Averill et al., 2003). The US "Medicare" program, introduced in 1983, was the first federal program that

1 This paper is a result of Croatian Science Foundation's funding of the project 8509 "Accounting and financial reporting reform as a means for strengthening the development of efficient public sector financial management in Croatia”. Any opinions, findings, and conclusions or recommendations expressed in this material are those of the authors and do not necessarily reflect the views of Croatian Science Foundation. 
introduced adjustments to the activity based costing (ABC) method for financing health services (Wiley, 2005). The system is used to control the complexity of the medical work and has resulted in a diagnostic-therapeutic procedure (DTP) classification system that facilitates the grouping of patients based on individual patient treatment and the necessary costs. Therefore, the financing of public hospitals starts from the recording of costs and their standardization, which has become the basis for determining income.

In the Republic of Croatia, the financing of the healthcare system starts from the funds available for each public hospital, i.e., by creating revenue while neglecting the costs. It is logical to expect that the capacity, i.e., the number of contracted beds with the Croatian Health Insurance Fund (CHIF), affects the invoiced revenue and the bigger the hospital, the more contracted beds there are and therefore the realization of revenues is better.

However, increased revenues are causing the consumption of certain resources and the creation of costs. In addition, capacity utilization depends on many other factors (types of patients, types of medical services, bottlenecks that occur between departments, sick leaves, adequacy of medical staff, etc.). The development of external financial reporting based on a modified accrual basis has also contributed to the neglecting of costs in the Croatian NHS, since it ignores the record of costs, in particular depreciation costs, which are substantial in large public hospitals. Because of the financial crisis, CHIF is constantly changing achievable revenues via DRG and DTP methodology of financing public hospitals. However, costs remain constant or they even increase, which leads to non-profitability and accumulated debt of individual public hospitals that consume high fixed costs. Pursuant to the Rehabilitation Law for public institutions (Official Gazette, No. 136/2012, 151/2014), in 2013 the government decided to rehabilitate the nine largest public hospitals founded by the Republic of Croatia, and later the process of rehabilitation covered another 14 health institutions owned by regional and local governments. In total, 23 public hospitals were included. Today the number of public hospitals that are going 
through the process of rehabilitation is 31 out of 57 . The rehabilitation process was initiated in public hospitals due to the impossibility to cover losses incurred and meet financial obligations within defined deadlines from regular funding sources.

However, financial sustainability of public hospitals in Croatia could be achieved through the use of reliable, timely and accurate information about costs, their allocation to health services and patients, and through applying cost management at all levels of decision making in public hospitals. Given all of the above, it is reasonable to conclude that the Croatian NHS is ready for a change (Vašiček et al., 2016). Therefore, if the funds for financing public hospitals are limited, then the public hospitals should turn to themselves and internally try to reduce and control the costs. The key change, which is the prerequisite for a number of other changes and improvements, is the monitoring of all costs in hospitals. This could be done with the introduction of a cost accounting methodology in the Croatian NHS, which has a foothold in the Rehabilitation Law for public institutions (Official Gazette, No. 136/2012, 151/2014). Therefore, it would be necessary to determine the costs of the provided health service or for the individual patient. However, in order to mobilize costs in the healthcare system in an optimal manner, it is necessary to provide an adequate information basis that relies primarily on an adequate method of cost accounting. This is achievable through the introduction of the full accrual accounting basis in the healthcare system or through the development of special modules for internal allocation that would rely on the record based on the modified accrual basis.

In order to successfully manage public hospitals, it is crucial that true, timely and valid information is obtained as a base for the decision making process. The cost accounting methodology is essential to the management of public hospitals. It must provide information about the type and amount of resources spent, and thus enable the prerequisites for: control, management and potential reduction of costs. In addition to the aforementioned preconditions, it is important to have the political will or the awareness of individuals regarding the need for internal 
cost accounting, with the aim of providing the best possible healthcare service with the optimal mobilization of costs. Through information obtained, we can monitor the accomplishment of various set goals and objectives for the Croatian NHS. Thus, the goal of achieving more effective and more efficient management and raising the awareness of responsibility in administration of public hospitals and their employees could be fulfilled.

The purpose of this paper is to present the current usage of cost accounting methodology in Croatian public hospitals through conducted empirical research and to provide opinions of accountants and financial officers regarding possible implementation of cost accounting methodology in public hospitals. In the second part of the paper, the authors comprehensively analyze the accounting system in Croatian public hospitals. In that way, the authors provide information about the flaws of the current accounting system with regard to the recording and allocation of costs. The third part presents the theoretical background on the usage of accrual accounting basis and cost accounting methodologies in the NHSs of different European countries. In the fourth part of the paper, empirical research results are given. At the end of the paper, the authors also give relevant recommendations for the introduction of the accrual accounting basis and cost accounting system in the Croatian NHS, which could be very helpful, not just for the management process in Croatian hospitals but also for all hospitals that have similar problems with the financing system.

\section{Accounting System in Croatian Public Hospitals}

The period from the beginning of 2002 until today has been marked by the intensification of reforms in the Croatian public sector, including the reform of national accounting practices. Leaving the concept of cash accounting and fund accounting and at the same time introducing the concept of modified accrual accounting basis was a further step towards modern international trends. Simultaneously, relevant international classifications have been comprehensively 
and consistently introduced in the reporting system to ensure transparency and comparability of the state and its entities. A reform in the financing of the public health system has changed the status of CHIF from an extra-budgetary user to a part of the central government budget through the State Treasury. Thus, public hospitals in the healthcare system are financed through contributions from CHIF, and behave in accordance with the established standards at the central government (Ministry of Health) but in terms of the accounting regulations they are a classic form of budget user. However, a specific trait of the public health system is that the health institutions as budget users are not financed exclusively by certain types of expenditure approved in the financial plan, but based on the actual provision of services, within the framework of a contract with CHIF, or the state, which through public hospitals indirectly provides health services to citizens (Vašiček and Roje, 2010). The financial reform of the public health sector is included in the mandatory application of the current national accounting system based on the modified accrual accounting basis. The legal basis today of the current accounting system of public hospitals includes the Budget Law (Official Gazette, No. 136/2014), the Regulation on Budget Classifications (Official Gazette, No. 26/2010) and the Regulation on Budget Accounting and Planning (Official Gazette, No. 124/2014).

The modified accrual accounting basis in particular has the following main features (Vašiček, Dražić Lutilsky and Jovanović, 2015):

1. Expenses are defined as decreases in economic benefits during the reporting period, which means that they are recognized at the time of the transaction, regardless of the time of payment.

2. Revenues are defined as an increase in economic benefits during the reporting period in the form of inflows of cash and cash equivalents, which undoubtedly refers to the recognition of revenue retained at cash concept.

3. Revenues and expenses due to changes in the value and volume (value adjustments, deficits/surpluses, write-offs...) of non-financial assets and 
liabilities are not recognized, but these changes are reflected directly in ownership sources (public capital).

4. Costs of acquisition of non-financial fixed assets are not capitalized but they are entirely recognized as expenses of the period in which the acquisition occurs. Consequently, healthcare entities do not account for depreciation of the asset as well as the systematic allocation of the cost over the useful life of its usage, which directly undermines the possibility of monitoring the efficiency of activities.

5. Also, in direct connection with the aforementioned, the recognition of funds received from the founders (the state and local government) to finance investments in assets, is not carried out according to the economic logic of the international accounting standards (profit or capital approach), but is recognized as a part of total revenues of the reporting period in which they are realized.

6. Acquisition or disposal of non-financial assets free of charge (donations) in the framework of the budget is not recognized as income or expense but is directly expressed as a change in ownership sources (public capital).

From the accounting point of view, it can be highlighted that in Croatian public hospitals revenues are not aligned with the expenses due to the modified accrual accounting basis. This is why it is impossible to achieve financial sustainability of the Croatian NHS.

Public sector financial sustainability is the financial capacity of the public sector to meet its current obligations, to withstand shocks, and to maintain service, debt, and commitment levels at reasonable levels relative to both national expectations and likely future income, while maintaining public confidence (Anderson, 2013). The main problem of financial sustainability manifests itself through accounting and how revenues and expenses are aligned. Therefore, financial sustainability of the healthcare sector as the biggest part of the Croatian public sector can be 
observed through the accrual accounting basis, which allows introduction of cost accounting. In that sense, expressed revenues would be aligned appropriately with expenses incurred for provided healthcare services.

It should be noted that, since the beginning of 2015, CHIF as the dominant "buyer" of public health services, after 13 years of functioning in the framework of the State Treasury, regained its financial independence. This fact, however, did not cause any change in the budget and the accounting status of public hospitals as was the case when CHIF was included in the State Treasury. For public hospitals that are fully owned by the central government, this change has resulted in additional reporting requirements towards CHIF and the Ministry of Health as dominant stakeholders.

From the position of public hospitals, external reporting is divided in accordance with the provisions of the Budget Law and CHIF. However, despite such a complex and challenging external reporting process, the fact remains that public hospitals are missing information needed to make business decisions and to manage hospitals in the short and long term. Accounting information systems in public hospitals are focused on assembling external financial statements. Internal reports needed for governing public hospitals are used occasionally, as the result of the current management demand, and not the quality of developed cost accounting and management accounting methodologies (Vašiček et al., 2016). The research conducted to assess the quality of accounting information for management purposes in public hospitals tests the hypothesis that the current accounting system is not appropriate for the needs of objective monitoring of activities and presentation of the results of public hospitals (Vašiček et al., 2011). Looking at the results of the research and ranking the importance of reasons for using the prescribed system of financial reporting, it is visible that the most important reason for using the prescribed financial reporting system is meeting the statutory reporting obligations. The other reasons, in order of importance, are: the execution of the financial plan, the successful conduct of business policy and benchmarking with other equivalent institutions (Vašiček et al., 2011). 
The methodological basis for preparation of internal reports and selection of a suitable cost accounting methodology should take into account the specifics of the processes, management information requirements and development of the business and accounting system. It must be consistent with the purpose, goals and objectives of public hospitals and must ensure quality and complete internal reporting at all hierarchical levels of management (Vašiček et al., 2011). In order to achieve that, it would be appropriate to introduce the accrual accounting basis which would allow recording and recognition of all costs and expenses. It would also allow allocation of costs to the patient or to the healthcare services, thus providing the transparency of resources spent in the healthcare system. From the perspective of public hospitals, the introduction of the accrual accounting basis and cost accounting methodology enables them to cut costs and to reduce piled-up debt.

\section{Theoretical Background}

It can be said that the main purpose of any healthcare system is to improve the value of provided services to the patients (Porter, 2010). According to Kaplan and Porter (2011), value in the healthcare system is measured through the patients' outcomes achieved through the consumed resources. Thereby, the realized value of patients' outcomes is more important than the number or volume of different health services. More services or services that are more expensive do not necessarily mean better value or better healthcare system. In order to successfully manage the value of healthcare services, patient outcomes and costs of the services provided must be measured at the level of the patient. Measuring outcomes and costs must be enabled for the entire cycle of special medical condition of the individual patient, which often requires that multiple physicians perform multiple interventions, from diagnosis and treatment to administration. The formula for calculating the value of health services could be expressed as outcomes divided by costs (Porter, 2010). The outcomes of treatment, as the first component, measure the value observed for any medical condition or patient population. 
They should be measured through multiple dimensions, which include survival, ability to function, duration of healthcare, discomfort and complications as well as sustainability of the recovery. Measurements of costs that enable the outcomes are not under scrutiny in the same way as outcomes that are gaining increased attention at all levels. Relevant costs are the total costs of all resources such as medical and administrative personnel, medicines, medical supplies, equipment and space used throughout the cycle of healthcare of the patient in the treatment of specific medical conditions, including treatment-related medical conditions. The value of healthcare services is increased through improved treatment outcomes with similar or reduced costs, while maintaining the same quality of output. A strong value driver in the healthcare system is that better outcomes should bear lower total cost of treatment (Porter, 2010). Spending more on an early and better diagnosis and prevention often results in less complex and less expensive healthcare later. In the healthcare system (more than in any other) it is really possible to improve outcomes while reducing costs (Kaplan and Porter, 2011). To reach this potential, the key is to combine accurate measurement of the cost with the systematic measurement of treatment outcomes for patients.

In this way, healthcare providers could make the most of their medical personnel, equipment, facilities and administrative resources more efficiently by directing patients through the process of choosing medical treatments and procedures that improve outcomes, and thereby eliminating those which do not.

Therefore, in order to understand the costs of provided healthcare services, it is necessary to understand the accrual basis in accounting which enables the development of cost accounting methodologies such as the $\mathrm{ABC}$ method.

The accrual accounting basis as a basis for financial reporting and recording of transactions in business books has become a movement in the public sector over the past 20 years (Mehrolhassani and Emami, 2013). It is strongly connected with the system of new public management (NPM) which brings accounting reforms in public bureaucracies, introducing performance measurement and 
managerial control procedures in public sector entities (Eriotis, Stamatiadis and Vasiliou, 2011). In order to implement market-based principles in public sector entities (e.g., public hospitals, high education institutions) and in governments, and to achieve better budget transparency, it is necessary to provide relevant information based on the accrual accounting basis (Vašiček and Roje, 2010). According to Wynne (2004), the advantages of accrual-based accounting are comprehensive financial information, better asset management, calculation of full cost of public services, focus on outputs, better quality of management and decision making information, and greater comparability of management performance results which could lead to responsibility accounting in the public sector. The same author explains that the disadvantages are related to valuation of costs, development of accounting policies, establishment of costly accounting information systems and providing necessary skills for employees in accounting departments of public hospitals (Wynne, 2004). Up to the year 2000, only three countries had adopted the accrual basis at the national level: Chile in 1997, New Zealand in 1990 and the US in 1997 (Wynne, 2004). Since 2000, it has become a trend, if not at the national level, then in certain public entities such as public hospitals and high education institutions. According to the FEE Public Sector Committee's research from 2007, the countries that, across the levels of government, scored highly with accrual accounting basis include Denmark, Finland, Latvia, Estonia and the United Kingdom (FEE, 2007). Austria, Czech Republic and Lithuania are moving toward implementation. But from the available data in 2011, it is evident that Ireland (Connolly and Hyndman, 2011), France, Germany, Romania, Sweden, Portugal, Spain, Greece, Italy and Cyprus have also made considerable efforts to introduce the accrual accounting basis at the national level (FEE, 2011). It is also necessary to mention Australia and Canada, which are considered to be the most developed countries in the usage of the accrual accounting basis not only for financial reporting but also for budgeting purposes at all levels of government (Mehrolhassani and Emami, 2013). Regarding accrual accounting in public hospitals and cost accounting methodology (ABC method), we can argue that many of those countries 
have introduced the DRG methodology at the sectoral level for paying public health services provided by public hospitals (Polyzos et al., 2013; Christensen, Laegreid and Stigen, 2004; Pettersen, 2001; Helmig and Lapsley, 2001; SanchezMartinez et al., 2006). But in some countries like Ireland, Germany, France, Finland and UK, it was also introduced at the institutional level (O'Reilly et al., 2012). Moreover, it is important to emphasize that Bosnia and Herzegovina implemented the accrual accounting basis in public hospitals in 1998, and Slovenia did the same in 2001. Nevertheless, neither of these two countries has developed cost accounting methodologies in public hospitals (Vašiček, Dražić Lutilsky and Jovanović, 2015). So, it can be concluded that there are different combinations of the introduced accrual accounting basis: (1) introduction of accrual basis with the implementation of cost accounting in the public sector on the sectoral level for the determination of DRGs; (2) introduction of accrual basis with the implementation of cost accounting in the public sector on the sectoral level for the determination of DRGs and on the institutional level for cost accounting methodologies. However, there are also some countries that have just introduced the accrual accounting basis on the sectoral level without any real advantage at the institutional level. And there is Croatia, which is using a modified accrual accounting basis at the sectoral and at the institutional level.

\subsection{Implementation of Cost Accounting Methodology in Public Hospitals}

Cost accounting is a part of accounting in which all costs incurred in carrying out an activity or accomplishing a service are collected, classified and recorded (Horngren, Datar and Foster, 2003). This data are then summarized and analyzed to arrive at a production cost, or to determine where savings are possible. Cost accounting is considered an internally oriented accounting procedure, providing information about costs and processes to managers and stakeholders. Under cost accounting methodologies, the authors consider any cost allocation method that enables the calculation of costs per unit of product or service, such as the 
traditional costing system or modern costing system. O’Reilly et al. (2012) investigate the implementation of the $\mathrm{ABC}$ method in public hospitals in countries like Ireland, Germany, France, Finland and UK. The main purpose of their study was to investigate the reasons for the introduction of this cost methodology and its development and implementation. Through the selected countries, the research shows how the ABC methodology can be implemented in health systems with a different organizational structure, different systems of funding and involvement of various public and private sector entities in the provision of health services. Despite the differences in approaches and ways of implementing the $\mathrm{ABC}$ method as the basis for the financing of health institutions, countries share several common goals for implementation such as increasing efficiency, improving quality and improving transparency (O'Reilly et al., 2012). Each of the five countries adopted a different approach to comparing data with costs. The bottom-up approach is used in Germany and Finland, and is based on data per patient about the use of resources per unit cost. The cost per patient is considered a more accurate approach because it is based on real, rather than on the average use of resources. Due to the lack of data on costs per patient, in England, France and Ireland the top-down approach is used and involves the allocation of significant hospital costs to certain services and specializations. In the relatively short period of adoption of the ABC method, it has contributed to improving efficiency in complex healthcare institutions and to achieving financial sustainability of the healthcare system (O'Reilly et al., 2012). Moreover, it also enables better cost allocation and tracking of costs. The future direction of the $\mathrm{ABC}$ method is clear; further adjustments are necessary to fully consider the increasing emphasis on quality of care and creating value.

The ABC method is providing more accurate data for performance measurement of hospitals (O'Reilly et al., 2012). According to Agyar et al. (2007), the costs of medical procedures and operations calculated by the ABC method show a big difference in the consumption of resources compared to the traditional method of cost accounting. The use of bi-level cost allocation with the ABC method 
has improved allocation of indirect costs because it is a more detailed and more accurate allocation. Moreover, it takes into account the causal relationship between resources and activities through the utilization of resources and factors of the causal relationship between activities and the final cost objects through cost drivers. Aldogan, Austill and Kocakulah (2014) conclude that using the ABC method, managers will be able to get a more accurate allocation of indirect costs, which ultimately enables meaningful analysis of revenue and expenses and more accurate prices, hospital budgets and planning strategies.

Authors Dražić Lutilsky and Butorac (2014) point out that the ABC method ensures calculation of unit costs per service and patient, depending on the specific characteristics of individual hospitals and healthcare services offered. In this way, it is possible to determine the cost of hospital care for each individual patient and ascertain the correct and objective cost of health services in public hospitals. This method of cost calculation would enable more realistic reimbursement from CHIF and allow liquidity of hospitals. It would also allow hospitals to understand all of the costs incurred. In Croatia, the practice of determining fees for services typically is a political issue and a certain amount of fees have more political and social than economic rationale, which is ultimately wrong because it does not provide a realistic picture of the actual costs incurred (Dražić Lutilsky and Butorac, 2014). Finally, the authors emphasize that the introduction of the $\mathrm{ABC}$ method in the public hospital system would secure payment of services on the market, if the hospital decides to enter the market with certain services. That would enable the potential excellence of certain services and hospitals, but also provide new ways of financing.

In a paper based on the empirical research on 54 public hospitals in Greece, Stamatiadis (2009) concluded that although they used the accrual accounting basis, the observed public hospitals did not yet introduce cost accounting. Only 10 public hospitals out of 54 sampled introduced cost accounting into their accounting information systems. Even though all of them are satisfied with the possibilities provided by the accrual accounting basis, it seems that they are not 
using those possibilities completely (Stamatiadis, 2009). According to SanchezMartinez et al. (2006), out of 115 public hospitals, 75 percent use some kind of cost accounting methodology while the remaining 25 percent do not use any. The authors emphasize that cost accounting methodologies are promoted by the health authorities but the payments to the public hospitals are based on public tariffs. Because of that, the public hospitals are losing interest in cost accounting methodologies (Sanchez-Martinez et al., 2006). Bertoni et al. (2015) emphasize that the relevance of $\mathrm{ABC}$ information is associated with the ability to draw attention to the determinants of costs. Therefore, the ABC method is a valid support for decision making and a useful tool for the analysis of costs, but it does not necessarily represent the most efficient measurement of costs. Based on the analysis of activities, $\mathrm{ABC}$ systems are prone to a high rate of obsolescence, and their costs tend to be steep because the activities develop over time, especially in complex organizations. Traditional cost accounting systems, on the other hand, tend to be more stable and less expensive because the places of cost change less frequently than the activities (Bertoni et al., 2015). Unfortunately, the quality of information they provide is not at the same level as information given by the ABC method (Bertoni et al., 2015).

Finally, empirical research conducted in Croatia on 36 public hospitals indicates that the cost accounting methodology is underdeveloped (Vašiček and Roje, 2010). Research results about the application of cost accounting and management accounting methodologies show that cost accounting is used to a limited extent and with limited information, which affects the activities of public hospitals. The application and development of cost accounting should be observed primarily by monitoring the overall level of costs and cost structure by nature and places of costs. Monitoring the overall level of costs has special importance in the context of limited overall financial resources for the execution of contractual obligations regarding the volume of provided healthcare service. Monitoring costs per patient is not developed, and neither is performance measurement of the services provided (Vašiček and Roje, 2010). The authors conclude that it is necessary to 
significantly improve internal accounting in the public health system, and to introduce the accounting model based on the concept of accrual accounting. That would increase the degree of convergence of internal and external reporting (Vašiček and Roje, 2010).

\section{Research Objectives and Methodology}

In order to investigate to what extent cost accounting methodology is used in Croatian public hospitals and whether accountants and financial officers are ready for implementation of the accrual accounting basis and full cost approach for calculation of costs in order to track costs per patient or healthcare service, the authors examined and tried to answer the following research questions:

RQ1: Are the accountants and financial officers in public hospitals ready for the implementation of the accrual accounting basis?

RQ2: What do they see as a main constraint in the implementation of the accrual accounting basis?

RQ3: To what extent do public hospitals use cost accounting methodology?

RQ4: Is there a calculation of costs per patient or per provided service?

RQ5: Are the accountants and financial officers in public hospitals ready for the implementation of the full cost approach for calculation of costs in order to track costs per patient or healthcare service?

The principal area of research is to present the current opinion of accountants and financial officers in Croatian public hospitals about the research questions. In order to gather the necessary information and answer the questions above, an empirical research was done using questionnaires in December 2015 and January 2016 in all Croatian public hospitals. The survey was conducted as a part of the project 8509 "Accounting and financial reporting reform as a means for 
strengthening the development of efficient public sector financial management in Croatia”, financed by the Croatian Science Foundation. The questionnaires were sent by email in an online form to accountants and financial officers in 57 public hospitals. Out of 57 public hospitals, 34 responded to the questionnaire.

Table 1: Share of Public Hospital Respondents in Total Number of Hospitals According to the Type of Public Hospital

\begin{tabular}{l|c|c|c}
\hline Type of hospital & $\begin{array}{c}\text { Number of } \\
\text { hospitals }\end{array}$ & $\begin{array}{c}\text { Number of hospital } \\
\text { respondents }\end{array}$ & $\begin{array}{c}\text { Percentage of hospital } \\
\text { respondents in total number }\end{array}$ \\
\hline CHC, CH, C & 10 & 5 & 50.00 \\
\hline General hospitals & 21 & 13 & 61.90 \\
\hline Specialized hospitals & 26 & 16 & 61.54 \\
\hline Total & 57 & 34 & 59.65 \\
\hline
\end{tabular}

Source: Authors' calculations.

The response rate was as high as 59 percent. Most of the questions included in the questionnaire were multiple choice, yes or no answers or answers on a five-point Likert scale ranging from 1 to 5, where 1 indicates full disagreement and 5 indicates full agreement or in some cases 1 corresponds to the lowest degree and 5 to the highest. In addition, it is important to point out that the sample representativeness was tested according to the type of public hospital. The types of hospitals in Croatia are clinical hospital center (CHC), clinical hospital $(\mathrm{CH})$ and clinics $(\mathrm{C})$ as the first category, then general hospitals and specialized hospitals. The sample representativeness was tested by using the goodness-of-fit chi-squared statistical test. The test shows that the sample's distribution is not statistically significantly different from the distribution within the population of 57 Croatian hospitals (empirical chi-square $=0.1896$, degrees of freedom $=2$, p-value $=0.9096)$.

Table 2 shows certain population characteristics such as the number of contracted beds with CHIF in 2015. Contracted beds are the basis for healthcare service provision. The highest number of contracted beds is in the $\mathrm{CHC}, \mathrm{CH}$ and $\mathrm{C}$ category, and so is the number of employees. There are 26 specialized hospitals, 
21 general hospitals and only 10 hospitals belonging to the $\mathrm{CHC}, \mathrm{CH}$ and $\mathrm{C}$ category.

Table 2: Population Characteristics

\begin{tabular}{|c|c|c|c|c|c|c|}
\hline $\begin{array}{l}\text { Type of } \\
\text { hospital }\end{array}$ & $\begin{array}{l}\text { Number of } \\
\text { hospitals }\end{array}$ & $\begin{array}{c}\text { Structure } \\
\text { of } \\
\text { hospitals, } \\
\text { in } \%\end{array}$ & $\begin{array}{c}\text { Number of } \\
\text { contracted } \\
\text { beds with } \\
\text { CHIF in } \\
2015\end{array}$ & $\begin{array}{l}\text { Structure } \\
\text { of beds, } \\
\text { in } \%\end{array}$ & $\begin{array}{l}\text { Number of } \\
\text { employees } \\
\text { on Sept. 30, } \\
2014\end{array}$ & $\begin{array}{l}\text { Structure } \\
\text { of } \\
\text { employees, } \\
\text { in } \%\end{array}$ \\
\hline $\mathrm{CHC}, \mathrm{CH}, \mathrm{C}$ & 10 & 18 & 7,695 & 38 & 22,367 & 49 \\
\hline $\begin{array}{l}\text { General } \\
\text { hospitals }\end{array}$ & 21 & 37 & 6,504 & 32 & 17,308 & 38 \\
\hline $\begin{array}{l}\text { Specialized } \\
\text { hospitals }\end{array}$ & 26 & 46 & 5,865 & 29 & 6,364 & 14 \\
\hline Total & 57 & 100 & 20,064 & 100 & 46,039 & 100 \\
\hline
\end{tabular}

Source: Croatian Health Insurance Fund.

From the population characteristics, we can conclude that, by the number of contracted beds and by the number of employees, $\mathrm{CHC}, \mathrm{CH}$ and $\mathrm{C}$ are the largest hospitals. General hospitals are medium-sized, while specialized hospitals are small-type hospitals. When we look at the structure of hospitals, we can see that specialized hospitals make up 46 percent of the total number of hospitals, general hospitals account for 37 percent and $\mathrm{CHC}, \mathrm{CH}$ and $\mathrm{C}$ make up 18 percent of the total number of hospitals. Sample characteristics are given in Table 3.

Table 3: Sample Characteristics

\begin{tabular}{l|c|c|c|c|c|c}
\hline $\begin{array}{c}\text { Type of } \\
\text { hospital }\end{array}$ & $\begin{array}{c}\text { Number of } \\
\text { hospitals }\end{array}$ & $\begin{array}{c}\text { Structure } \\
\text { of } \\
\text { hospitals, } \\
\text { in \% }\end{array}$ & $\begin{array}{c}\text { Number of } \\
\text { contracted } \\
\text { beds with } \\
\text { CHIF in } \\
\mathbf{2 0 1 5}\end{array}$ & $\begin{array}{c}\text { Structure } \\
\text { of beds, } \\
\text { in \% }\end{array}$ & $\begin{array}{c}\text { Number of } \\
\text { employees } \\
\text { on Sept. 30, } \\
\mathbf{2 0 1 4}\end{array}$ & $\begin{array}{c}\text { Structure } \\
\text { of } \\
\text { employees, } \\
\text { in \% }\end{array}$ \\
\hline CHC, CH, C & 5 & 15 & 3,484 & 33 & 10,513 & 43 \\
\hline $\begin{array}{l}\text { General } \\
\text { hospitals }\end{array}$ & 13 & 38 & 3,595 & 34 & 9,984 & 41 \\
\hline $\begin{array}{l}\text { Specialized } \\
\text { hospitals }\end{array}$ & 16 & 47 & 3,569 & 34 & 3,963 & 16 \\
\hline Total & 34 & 100 & 10,648 & 100 & 24,460 & 100 \\
\hline
\end{tabular}

Source: Croatian Health Insurance Fund. 
From Table 3 it is visible that among public hospital respondents, 15 percent are large hospitals of $\mathrm{CHC}, \mathrm{CH}$ and $\mathrm{C}$ type, 38 percent of general hospitals are medium-sized, while 47 percent of specialized hospitals are small-type hospitals.

\subsection{Research Results}

To answer the first research question, accountants and financial officers in public hospitals were asked to state whether the current accounting system should be improved with the implementation of the accrual accounting basis in public hospitals. As many as 65 percent of the interviewed accountants and financial officers believe that the current accounting system should be improved with the implementation of the accrual accounting system that would expand the scale of available accounting information. Figure 1 shows that only a small number of specialized hospitals oppose the implementation of the accrual accounting basis. A small portion of general and specialized hospitals do not have an opinion about the implementation of the accrual accounting basis.

Figure 1: Opinion of Accountants and Financial Offcers about Implementation of Accrual Accounting Basis in Public Hospitals, $n=34$

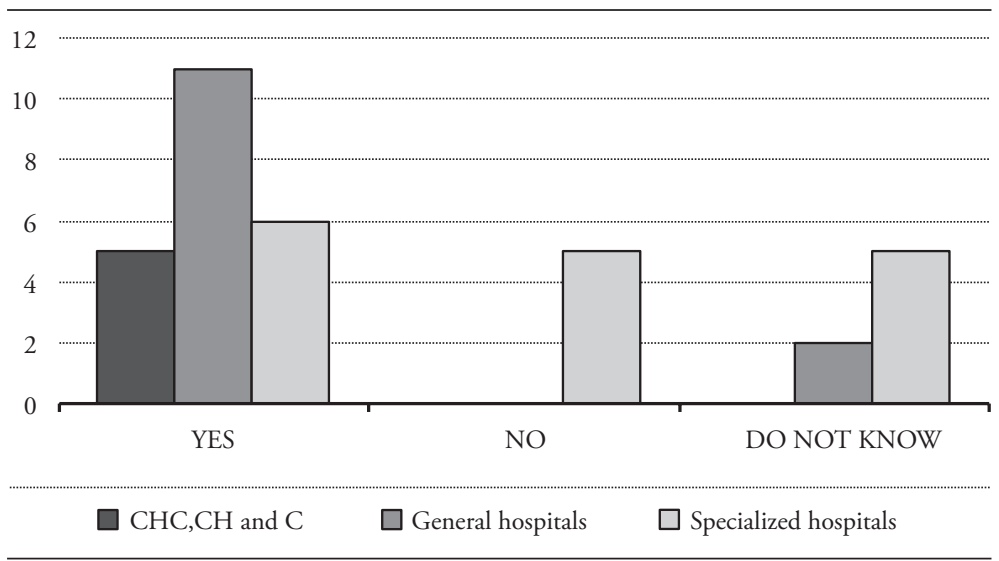

Source: Authors' calculations. 
This direct question posed to the accountants and financial officers in public hospitals answers the first research question. Accountants and financial officers in public hospitals are ready for the implementation of the accrual accounting basis in the accounting system.

The second research question investigates what accountants and financial officers see as a main constraint in the implementation of the accrual accounting basis. Again, the authors asked the respondents about their perception of constraints.

Table 4: Constraints in Implementation of Accrual Accounting Basis

\begin{tabular}{|c|c|c|c|c|c|c|c|c|}
\hline \multirow{2}{*}{ Constraints } & \multicolumn{5}{|c|}{ Response structure, in \% } & \multirow{2}{*}{ Average } & \multirow{2}{*}{$\begin{array}{l}\text { Standard } \\
\text { deviation }\end{array}$} & \multirow{2}{*}{ Rank } \\
\hline & 1 & 2 & 3 & 4 & 5 & & & \\
\hline $\begin{array}{l}\text { Human } \\
\text { resources }\end{array}$ & 6.3 & 6.3 & 21.9 & 31.3 & 34.4 & 3.81 & 1.176 & 5 \\
\hline $\begin{array}{l}\text { Financial } \\
\text { resources }\end{array}$ & 3.1 & 9.4 & 18.8 & 37.5 & 31.3 & 3.84 & 1.081 & 4 \\
\hline IT support & 3.2 & 3.2 & 22.6 & 38.7 & 32.3 & 3.94 & 0.998 & 3 \\
\hline $\begin{array}{l}\text { Long duration } \\
\text { and complexity } \\
\text { of the process }\end{array}$ & 0.0 & 6.3 & 34.4 & 34.4 & 25.0 & 3.78 & 0.906 & 6 \\
\hline $\begin{array}{l}\text { Political and } \\
\text { legislative } \\
\text { support }\end{array}$ & 0.0 & 3.1 & 25.0 & 31.3 & 40.6 & 4.09 & 0.893 & 2 \\
\hline $\begin{array}{l}\text { Support of } \\
\text { administration } \\
\text { and management } \\
\text { of hospitals }\end{array}$ & 0.0 & 0.0 & 20.0 & 20.0 & 60.0 & 4.40 & 0.814 & 1 \\
\hline
\end{tabular}

Source: Authors' calculations.

From Table 4 it is visible that the highest average grade is given to the constraint support of administration and management of hospitals with an average grade of 4.40. In second place accountants and financial officers grade the constraint of political and legislative support with an average grade of 4.09. The constraint IT support is in third place, while the fourth and fifth places belong to financial resources and human resources, respectively. In sixth place is the long duration and complexity of the process. From the results, we can conclude that accountants and financial officers see the support of administration and management of hospitals 
as extremely important for the implementation of the accrual accounting basis or as the main constraint to it. This may be due to the fact that physicians with little accounting and financial knowledge are in top management positions of public hospitals. This may also indicate that top management does not understand the issues regarding the accounting system. Also, the ranking of the constraint long duration and complexity of the process in sixth place was surprising.

According to Stamatiadis (2009), the process of implementation of the accrual accounting basis in Greek public hospitals was very complex and time and resource consuming. From the 45 public hospitals that had implemented the accrual accounting basis, 60 percent saw the implementation of the accrual accounting basis as a very difficult and long-term process (Stamatiadis, 2009). Therefore, we can conclude that Croatian accountants and financial officers are not acquainted with the process of the implementation. Their opinion is that, if they get the support from management and politics, it would be easier to implement the accrual accounting basis.

Research questions 3 and 4 are connected. In the third research question, the authors asked to what extent public hospitals used cost accounting methodology and in the fourth research question the authors were interested to find out whether there was a calculation of costs per patient or per provided service. Calculation of costs per patient or per provided service is a result of cost accounting methodology. In order to test the hypothesis that the usage of cost accounting methodology is very poor in Croatian public hospitals, the authors asked the respondents how they calculated costs and to rank the usage of cost accounting methodology from 1 to 5,1 being the lowest and 5 being the highest grade of use. 
Table 5: Sign Tests for Median and Wilcoxon Signed Rank Test Results for Calculation of Costs Variable

\begin{tabular}{|c|c|c|c|c|}
\hline $\begin{array}{c}\text { Calculation of } \\
\text { costs }\end{array}$ & $\begin{array}{l}\text { Statistical } \\
\text { hypotheses }\end{array}$ & Statistical test & p-value & $\begin{array}{c}\text { Decision, } \\
\text { significance } \\
\text { level } 1 \%\end{array}$ \\
\hline \multirow{2}{*}{$\begin{array}{l}\text { By nature for the } \\
\text { whole hospital }\end{array}$} & \multirow{2}{*}{$\begin{array}{l}H_{0} \ldots \eta=5 \\
H_{1} \ldots \eta \neq 5\end{array}$} & Sign test for median & 0.016 & Ho \\
\hline & & Wilcoxon signed rank test & 0.022 & $\mathrm{Ho}$ \\
\hline \multirow{2}{*}{$\begin{array}{l}\text { Per place of cost or } \\
\text { organizational unit }\end{array}$} & \multirow{2}{*}{$\begin{array}{l}H_{0} \ldots \eta=4 \\
H_{1} \ldots \eta \neq 4\end{array}$} & Sign test for median & 0.424 & $\mathrm{Ho}$ \\
\hline & & Wilcoxon signed rank test & 0.957 & $\mathrm{HO}$ \\
\hline \multirow{2}{*}{$\begin{array}{l}\text { Per type of provided } \\
\text { service (DRG and } \\
\text { DTP) }\end{array}$} & \multirow{2}{*}{$\begin{array}{l}H_{0} \ldots \eta=3 \\
H_{1} \ldots \eta \neq 3\end{array}$} & Sign test for median & 0.078 & Ho \\
\hline & & Wilcoxon signed rank test & 0.110 & $\mathrm{Ho}$ \\
\hline \multirow{2}{*}{$\begin{array}{l}\text { Per type of } \\
\text { service in internal } \\
\text { calculation of costs }\end{array}$} & \multirow{2}{*}{$\begin{array}{l}H_{0} \ldots \eta=2 \\
H_{1} \ldots \eta \neq 2\end{array}$} & Sign test for median & 1.000 & $\mathrm{Ho}$ \\
\hline & & Wilcoxon signed rank test & 0.578 & $\mathrm{Ho}$ \\
\hline \multirow{2}{*}{ Per patient } & \multirow{2}{*}{$\begin{array}{l}H_{0} \ldots \eta=2 \\
H_{1} \ldots \eta \neq 2\end{array}$} & Sign test for median & 0.078 & Ho \\
\hline & & Wilcoxon signed rank test & 0.357 & $\mathrm{Ho}$ \\
\hline
\end{tabular}

Source: Authors' calculations.

At the 1 percent level of significance, it can be concluded that the median score in the category by nature for the whole hospital is equal to 5 . In other words, at least 50 percent of the hospitals mostly use cost calculation by nature for the whole hospital. On the other hand, the median score in the category per place of cost or organizational unit is equal to 4. Accordingly, it is concluded that 50 percent of the institutions have a high level of use per place of cost or organizational unit. Further, it can be concluded that the frequency of use by nature for the whole hospital is higher than the frequency of use by place of cost or organizational unit. From the results, we can observe that for the category per type of provided service (DRG and DTP) the median score is equal to 3 , which means that some of the hospitals calculate costs per provided service (by DRG and DTP classification). DRG and DTP represent a basis for invoicing to CHIF. We can conclude that they calculate some costs per invoiced revenue to CHIF. Per type of service in 
internal calculation of costs and per patient, as the most important levels from the cost accounting point of view, got a median score equal to 2 . It can be concluded that accounting officers in public hospitals rarely calculate costs per provided service from internal cost calculation and per patient, which leads to the conclusion about the poor usage of cost accounting methodology in Croatian public hospitals. The mode or the most common given grade by hospitals in the sample for cost calculation by nature for the whole hospital and per place of cost or organizational unit was 5 . On the other hand, the other three methods of cost calculation were graded with grade 1.

Table 6: Results of Tests on Assumed Proportion Value for Allocation of Direct and Indirect Costs

\begin{tabular}{l|c|c|c|c|c}
\hline Question & $\begin{array}{c}\text { Alternative } \\
\text { hypothesis }\end{array}$ & $\begin{array}{c}\text { Number of yes } \\
\text { answers in the } \\
\text { sample }\end{array}$ & $\begin{array}{c}\text { Sample } \\
\text { size }\end{array}$ & $\begin{array}{c}\text { Sample } \\
\text { proportion }\end{array}$ & p-value \\
\hline $\begin{array}{l}\text { Do you allocate direct } \\
\text { costs to places of costs or } \\
\text { organizational units? }\end{array}$ & $H_{1} \ldots p>0.66$ & 26 & 31 & 0.84 & 0.023 \\
$\begin{array}{l}\text { Do you allocate indirect } \\
\text { costs to places of costs or } \\
\text { organizational units? }\end{array}$ & $H_{1} \ldots p \neq 0.66$ & 18 & 31 & 0.58 & 0.449 \\
\hline
\end{tabular}

Note: In the analysis, exact p-value was used. Source: Authors' calculations.

At the significance level of 5 percent, it is concluded that more than two thirds of the institutions ( 66 percent) allocate direct costs to places of costs or organizational units, while at the significance level of 5 percent we cannot reject the assumption that just two thirds of the institutions (66 percent) allocate indirect costs to the places of costs or organizational units. Out of 31 hospitals, only 18 responded that they allocate indirect costs (i.e., electricity, water, heating, etc.) using direct methods - directly through one or more selected allocation bases. For allocation of indirect costs most of them use the number of employees and the total costs (without depreciation) as an allocation base. From individual responses it is visible that the accountants and financial officers use different allocation bases for the allocation of indirect costs, which means that they take into account the nature 
of the cost and different costs are allocated over the different allocation bases. We can conclude from the research results that the accountants and financial officers allocate costs to places of costs. That is the first level of allocation under the traditional costing systems such as job order. The second level of allocation would be allocation to patients or provided services. From the previous question it is visible that ranking of cost calculation per patient or per provided service is very low.

The fifth research question was formulated so as to get the opinion from accountants and financial officers in public hospitals about the readiness for implementation of the full cost approach for calculation of costs in order to track costs per patient or healthcare service. We asked them yes or no questions about their perception of whether the current accounting system could be improved for efficient governance of public hospitals in Croatia. The sample size in this question was 31 .

Figure 2: Perception about Improvement of the Current Accounting System

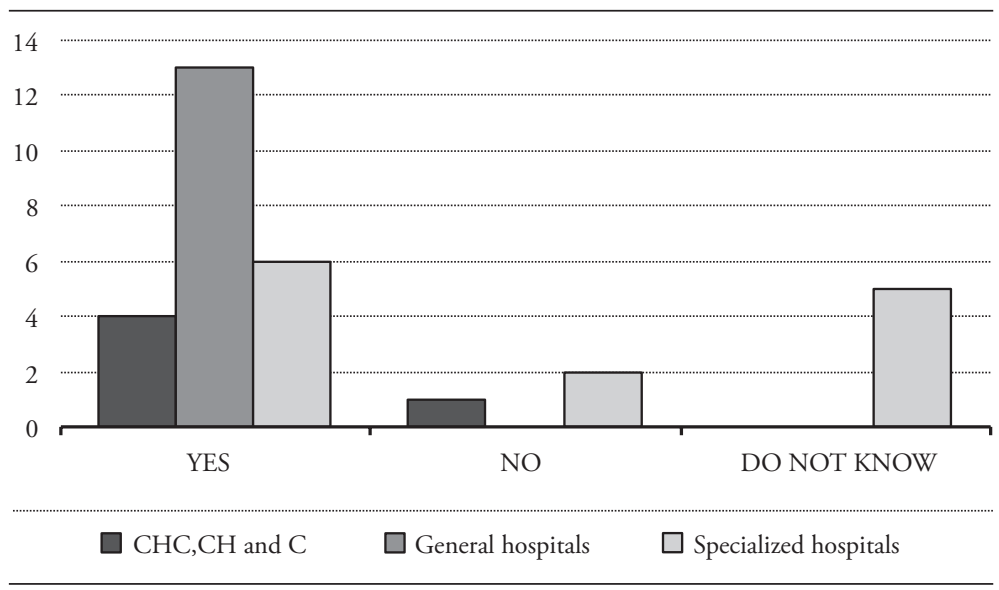

Source: Authors' calculations.

From Figure 2 it is visible that the accountants and financial officers believe that the current accounting system could be improved for better governance of public 
hospitals. In total, 74 percent were yes answers, 10 percent no and 16 percent $I$ do not know. When we observe the results by the type of hospital, we can see that almost all of the largest hospitals $(\mathrm{CHC}, \mathrm{CH}$ and $\mathrm{C}$ ) are in favor of the improvement, and so are all of the medium-sized hospitals (general hospitals) as well as six of the specialized hospitals. Some of the specialized hospitals did not opt for the improvement and it would be interesting to find out why. In five specialized hospitals, the accountants and financial officers do not know whether the current accounting system should be improved.

Figure 3: Perception about Improvement of the Current Accounting System with the Full Costing Approach

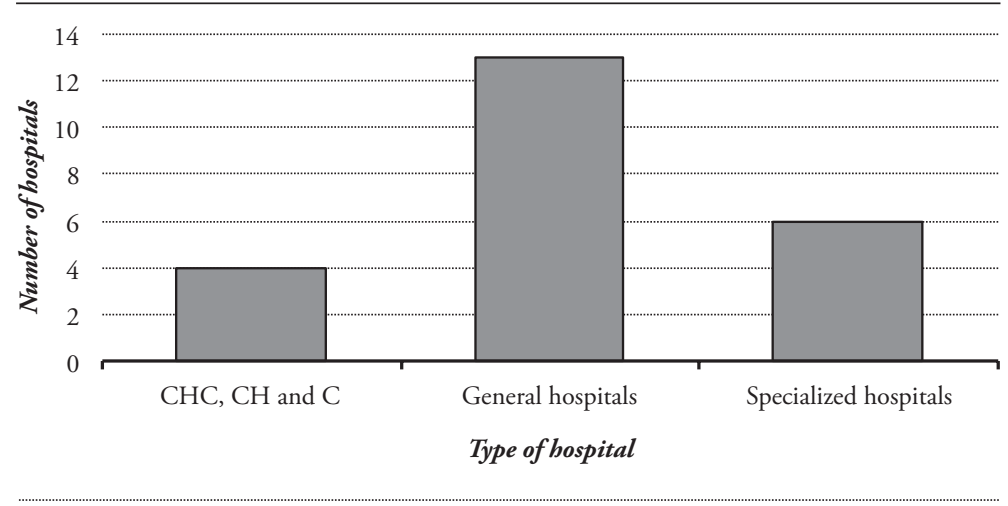

Implementation of full costing method for tracking of all direct and indirect costs per services or per patient

Source: Authors' calculations.

In the questionnaire, we asked the respondents how they would improve the current accounting system and 91 percent of them answered with the implementation of the full costing approach for calculation of costs in order to track costs per patient or healthcare service. All of the accountants and financial officers that answered yes to the previous question believe that the implementation of the full costing approach for calculation of costs in order to track costs per 
patient or healthcare service would be an improvement to the current accounting system in public hospitals. Answers per type of hospital are given in Figure 3.

\subsection{Conclusion Remarks about Research Results}

It can be concluded that the research questions are answered through statistical analysis of the answers given by the accountants and financial officers from Croatian public hospitals. Out of 34 interviewed accountants and financial officers, 65 percent believe that the implementation of the accrual accounting system in the current accounting system would expand the scale of available accounting information. The research results suggest that they believe that with the accrual accounting basis they would obtain reliable, timely and accurate information about costs, which would result in better governance in public hospitals. They see better governance through the implementation of the full costing approach for calculation of costs (direct and indirect) in order to track costs per patient or healthcare service provided. As the main constraint to the improvement of the accounting system in public hospitals, accountants and financial officers see the support from management, or rather, the lack of support. This is followed by political support and in third place as an important constraint they see IT support. The ranking of constraints based on the perceptions of accountants and financial officers is important because it expresses their opinion about the lack of understanding from management and politics, but also about the low investments in the accounting information systems of public hospitals. The management of the hospitals is usually comprised of physicians and maybe this constraint can be removed with some cost accounting education about the importance of cost accounting information. By starting to follow European trends, the constraint regarding political support could be removed. The Ministry of Health should understand that financial sustainability of the Croatian public healthcare sector cannot be viewed only from the perspective of users and medicine but notably through the costs of patients or provided services aligned with revenues. Similar conclusions are drawn from the 2008 research in Croatia done by Vašiček and 
Roje (2010). The follow-up of this research shows that after eight years nothing has changed except the financial position of hospitals and the healthcare system as a whole.

The limitations of this research can be attributed to lacking field research which would provide the reasons for the accountants' and financial officers' answers.

Future research should focus on field research on a sample of $\mathrm{CHC}, \mathrm{CH}$ and $\mathrm{C}$ hospitals, general hospitals and specialized hospitals to find out the individual reasons for the answers given in the surveys regarding the implementation of the accrual accounting basis, full costing approach and constraints.

\section{Recommendations for Introduction of Cost Accounting in Croatian Public Hospitals}

Before any implementation of the cost accounting system, it is necessary to define the objective, purpose and necessary resources for the implementation (human resources, additional education, additional material resources, additional records, IT support, etc.). Tracking and monitoring of all direct and indirect costs for each patient or service provided in a hospital and method of cost allocation should be defined for every single hospital. The introduction of a centralized system that would serve as a control mechanism for the Ministry of Health and CHIF is an erroneous idea, because for public hospitals that would only mean extra work in the form of additional analytics and submitting additional reports that mostly consume time and money. The cost accounting system should be designed internally, in such a way that the results of the analysis are available not only to the management of the institution, but also to managers of organizational units. Managers of organizational units are important because their work has a direct impact on the structure of costs and revenues, and internal reports based on costs should be mainly adjusted to them. Also, with the introduction of internal reports it is necessary to define the responsibilities of employees, but also to motivate them and at the end to reward them. The whole system should be 
redesigned, because formal introduction of additional records and monitoring alone would not produce the necessary effect. The $\mathrm{ABC}$ method, but also timedriven $\mathrm{ABC}$ method (TDABC method), is most frequently mentioned in both foreign and domestic literature as the cost allocation method that should be used in healthcare systems. In the analysis of the application of $\mathrm{ABC}$ methods in healthcare systems, the authors have noticed differences in the implementation of the methodology, techniques of data collection and the environment in which the method is implemented. The most prominent advantage of the $\mathrm{ABC}$ method is that its results, the determination and allocation of costs, provide more realistic cost estimates. This is achieved mainly in a way that the total costs are allocated to patients or to provided services according to factors with which they are most closely associated, i.e., the causality principle. Currently, in Croatia there are no manuals containing practical instructions for implementing the $\mathrm{ABC}$ method in the public sector, especially in hospitals. The reason for this lies in the fact that each hospital has a different organizational and functional structure, set of programs and activities, as well as type of services and consumed cost and different types of patients, and therefore generates different outcomes and problems. Despite all the problems and demanding process of introduction of cost accounting, the effort is definitely worth it. Implementation of cost accounting has a number of management functions such as budgeting, control and decrease of costs, pricing and reimbursement, measurement (assessment) of activities, evaluation of the program and the possibility of making economic choices, instead of observing it only through its historic role in determining the value of inventories or other assets in financial accounting. In addition, the introduction of cost accounting is a necessity and a precondition for effectiveness and efficiency in the healthcare system, which will be carried out only after the application of a number of techniques and methods of cost allocation tailored for each Croatian hospital. 


\section{Conclusion}

This paper aims to show the importance of cost accounting methodology as a possible solution for achieving financial sustainability of Croatian public hospitals. Croatian public hospitals are considered non-profitable because of the accumulated debt over the years. When introducing DRG and DTP classification as a provision for provided healthcare services, CHIF neglects the actual incurred costs of provided healthcare services. This leads to the fact that public hospitals cannot cover all incurred costs with the collected revenue from CHIF. Therefore, if the revenues are limited, management of public hospitals should turn to the control of costs. The argument is that with the introduction of the cost accounting system for internal purposes in public hospitals, management would be able to govern in a more efficient and effective way while reducing costs. From the theoretical background, it is visible that cost allocation methods introduced in the healthcare sector bring benefits to the whole society through provided healthcare services consuming fewer resources. But primarily it ensures better governing of hospital resources, allowing transparency of spent public money. The conducted empirical research based on a sample of 34 public hospitals was aimed at answering five research questions. The authors investigate whether the accountants and financial officers are ready for the implementation of the accrual accounting basis as a preamble for implementation of cost accounting methodology in public hospitals. Out of the 34 hospital respondents, 22 express the opinion that they are ready for the implementation of the accrual basis. Accountants and financial officers recognize the constraints to the implementation of the accrual accounting basis in the current accounting system. As the biggest constraint they see the support from management and administration, then political support and IT support. This leads to the conclusion that even if a political decision to that end was not made for the whole NHS, they would still implement the new accounting basis at institutional level, as long as they had support from management. Furthermore, the authors investigate the current usage of cost accounting methodology in public hospitals. From the conducted statistical test, 
based on the accountants' and financial officers' responses, it can be concluded that the usage is very poor, since they currently calculate costs primarily by nature for the whole hospital and then per place of cost or organizational unit. Allocation of direct and indirect costs is done mainly on the basis of place of cost or organizational unit and only a negligible number of accountants and financial officers calculate costs per type of provided service and per patient. That is the first level of cost allocation under traditional costing methods. The second level of cost allocation, i.e., allocation to patient and to provided service, is not done in Croatian public hospitals. Accountants and financial officers see the improvement of governance in public hospitals through implementation of the full costing approach for calculation of all costs in order to track costs per patient or per provided service. The full costing approach is a precondition for development of internal reports about costs that should be produced not only for top management, but also for the managers of organizational units. From the research results, it can be concluded that the accountants and financial officers in Croatian public hospitals are ready for a change in the accounting system and that they believe it can be achieved with the implementation of the accrual accounting basis and cost accounting methodology.

The limitation of this paper is that it only investigates the accounting system and does not take into consideration the social, political and other economic influences on financial sustainability of the Croatian NHS. 


\section{Literature}

Agyar, Evren, Ayten Ersoy, Mehmet Baykara and Murat Ucar, 2007, "A Practical Application of Activity Based Costing in an Urology Department", paper presented at the " $7^{\text {th }}$ Global Conference on Business and Economics", Rome, October 13-14.

Aldogan, Mehtap, David A. Austill and Mehmet C. Kocakulah, 2014, "The Excellence of Activity-Based Costing in Cost Calculation: Case Study of a Private Hospital in Turkey", Journal of Health Care Finance, 41(1), pp. 1-25.

Anderson, Bruce, 2013, "Public Sector Financial Sustainability", Discussion Paper, May, Wellington: Office of the Auditor-General.

Averill, Richard, Norbert Goldfield, Jack S. Hughes, Janice Bonazelli, Elizabeth C. McCullough, Barbara A. Steinbeck, Robert Mullin and Ana M. Tang, 2003, "All Patient Refined Diagnosis Related Groups (APR-DRGs): Methodology Overview", Wallingford, CT: 3M Heath Information Systems, https://www. hcup-us.ahrq.gov/db/nation/nis/APR-DRGsV20MethodologyOverviewandBibl iography.pdf (accessed February 15, 2016).

Bertoni, Michele, Bruno De Rosa, Guido Grisi and Alessio Rebeli, 2015, "Linking Cost Control to Cost Management in Healthcare Services: An Analysis of Three Case Studies" in Bryan Christiansen, ed., Handbook of Research on Global Business Opportunities, pp. 432-468, Hershey, PA: Business Science Reference. https:/doi.org/10.4018/978-1-4666-6551-4.ch021

Budget Law, Official Gazette, No. 136/2014.

Christensen, Tom, Per Laegreid and Inger Marie Stigen, 2004, "Performance Management and Public Sector Reform: The Norwegian Hospital Reform”, Stein Rokkan Centre for Social Studies Unifob AS Working Papers, No.17, December, Bergen: Uni Research Rokkan Centre.

Connolly, Ciaran and Noel Hyndman, 2011, "Accruals Accounting in the Public Sector: A Road Not Always Taken”, Management Accounting Research, 22(1), pp. 36-45. https:/doi.org/10.1016/j.mar.2010.10.008 
Dražić Lutilsky, Ivana and Nikola Butorac, 2014, "Mogućnost primjene metoda obračuna troškova temeljem aktivnosti u bolnicama”, Riznica, 11, pp. 17-27.

Eriotis, Nikolaos, Filippos Stamatiadis and Dimitrios Vasiliou, 2011, “Assessing Accrual Accounting Reform in Greek Public Hospitals: An Empirical Investigation", International Journal of Economic Sciences and Applied Research, 4(1), pp. 153-183.

Fédération des Experts Comptables Européens (FEE), 2007, “Accrual Accounting in the Public Sector”, http://www.unsceb.org/system/files/Finance\%20\%26\%20 Budget\%20Network/Accounting\%20Standards/ipsasf1609/ipsasfolder10/ europe2.pdf (accessed February 15, 2016).

Fédération des Experts Comptables Européens (FEE), 2011, Joint FEE and CNDCEC Public Sector Seminar "Challenges of Accrual Accounting in the Public Sector" - Tuesday January 11, 2011, Rome, Italy, http:/www.fee.be/ component/content/article.html?id=1312\&lang=en\&Itemid=106 (accessed February 15, 2016).

Helmig, Bernd and Irvine Lapsley, 2001, "On the Efficiency of Public, Welfare and Private Hospitals in Germany over Time: A Sectoral DEA Study", Health Services Management Research, 14(4), pp. 263-274. https:/doi. org/10.1258/0951484011912762

Horngren, Charles T., Srikant M. Datar and George Foster, 2003, Cost Accounting: A Managerial Emphasis, New Jersey: Prentice Hall.

Kaplan, Robert S. and Michael E. Porter, 2011, "How to Solve the Cost Crisis in Healthcare", Harvard Business Review, 89(9), pp. 46-52.

Mehrolhassani, Mohammad Hossein and Mozhgan Emami, 2013, "Change Theory for Accounting System Reform in Health Sector: A Case Study of Kerman University of Medical Sciences in Iran", International Journal of Health Policy and Management, 1(4), pp. 279-285. https:/doi.org/10.15171/ijhpm.2013.57 
O’Reilly, Jacqueline, Reinhard Busse, Unto Häkkinen, Zeynep Or, Andrew Street and Miriam Wiley, 2012 "Paying for Hospital Care: The Experience with Implementing Activity-Based Funding in Five European Countries", Health Economics, Policy and Law, 7(1), pp. 73-101. https:/doi.org/10.1017/ S1744133111000314

Pettersen, Inger Johanne, 2001, "From Book-Keeping to Strategic Tools - Some Aspects on the Role of Accounting in the Scandinavian Health Care Sector", Working Paper No.29/01, July, Bergen: Foundation for Research in Economics and Business Administration.

Polyzos, Nikolaos, Haralampos Karanikas, Eleftherios Thireos, Catherine Kastanioti and Nick Kontodimopoulos, 2013, "Reforming Reimbursement of Public Hospitals in Greece during the Economic Crisis: Implementation of a DRG System", Health Policy, 109(1), pp. 14-22. https:/doi.org/10.1016/j. healthpol.2012.09.011

Porter, Michael E., 2010, "What is Value in Health Care?", The New England Journal of Medicine, 363(26), pp. 2477-2481. https:/doi.org/10.1056/ NEJMp1011024

Regulation on Budget Accounting and Planning, Official Gazette, No. 124/2014.

Regulation on Budget Classifications, Official Gazette, No. 26/2010.

Rehabilitation Law, Offcial Gazette, No. 136/2012, 151/2014.

Sanchez-Martinez, Fernando, Jose-Maria Abellan-Perpinan, Jorge-Eduardo Martinez-Perez and Jaume Puig-Junoy, 2006, "Cost Accounting and Public Reimbursement Schemes in Spanish Hospitals", Health Care Management Science, 9(3), pp. 225-232. https:/doi.org/10.1007/s10729-006-9089-x

Stamatiadis, Filippos, 2009, "Governmental Accounting Reform in the Greek Public Hospitals: Some Preliminary Results of Its Implementation”, paper presented at the conference " $4{ }^{\text {th }}$ Hellenic Observatory $\mathrm{PhD}$ Symposium" at London School of Economics and Political Science, London, June 25-26. 
Vašiček, Davor, Ivana Dražić Lutilsky and Tatjana Jovanović, 2015, “Komparacija računovodstvenih sustava javnog zdravstva Republike Hrvatske, Slovenije i Bosne i Hercegovine", paper presented at the conference "II. Interdepartmental Symposium", Vlašić, Bosnia and Herzegovina, July 14-16.

Vašiček, Davor and Gorana Roje, 2010, "Accounting System in Croatian Public Healthcare Organizations: An Empirical Analysis", Theoretical and Applied Economics, 6(547), pp. 37-58.

Vašiček, Vesna, Ivana Dražić Lutilsky, Martina Dragija, Michele Bertoni, Bruno De Rosa, Guido Grisi, Alessio Rebeli, Jagoda Osmančević and Lucija Juroš, 2016, Procesni pristup obračunu troškova u sustavu zdravstva, Zagreb: Tim4Pin.

Vašiček, Vesna, Ivana Dražić Lutilsky, Martina Dragija, Milena Peršić, Mirjana Hladika, Sanja Broz Tominac, Verica Budimir, Vesna Bosilj Vukšić and Davor Vašiček, 2011, Upravljačko računovodstvo i računovodstvo troškova u javnom sektoru - izabrane teme, Zagreb: Hrvatska zajednica računovođa i financijskih djelatnika.

Wiley, Miriam, 2005, "Diagnosis Related Groups (DRGs): Measuring Hospital Case Mix" in Peter Armitage and Theodore Colton, eds., Encyclopedia of Biostatistics, Second Editon, Chichester: John Wiley \& Sons Ltd. https:/doi. org/10.1002/0470011815.b2a4a007

Wynne, Andy, 2004, "Is the Move to Accrual Based Accounting a Real Priority for Public Sector Accounting?", ACCA, https://www.researchgate.net/ publication/228263237_Is_the_Move_to_Accrual_Based_Accounting_a_ Real_Priority_for_Public_Sector_Accounting (accessed February 15, 2016). 